\title{
THE ESSENCE AND STRUCTURE OF MASTERS OF PUBLIC ADMINISTRATION CORE COMPETENCIES IN THE USA
}

\begin{abstract}
The article deals with revealing the essence and structure of Masters' of Public Administration professional training in the USA. It has been concluded that Public Administration studies the realization of government policies and trains future public administrators for professional activity; is guided by political science and administrative law; aims to improve the justice, equality, security and efficiency of public services. It has been indicated that the MPA degree is dedicated for those willing to work in public sector. It has been found out that MPA programs are designed to develop the abilities, skills and methods specialists use to realize policies, programs and projects as well as to resolve crucial issues within their organization and/or in society. It has been stated that in the United States of America Master of Public Administration (MPA) and Master of Business Administration programs $(M B A)$ are quite similar, however, have certain differences. It has been defined that the MPA program focuses on different ethical and sociological criteria secondary for business administrators. Simultaneously MPA programs encompass economy courses to supply students with knowledge of microeconomic and macroeconomic issues. It has been specified that MPA programs are built on a range of core competencies defined by the Network of Schools of Public Policy, Affairs, and Administration (NASPAA). The list of the core competencies (to lead and manage in public governance; to participate in and contribute to the public policy progress; to analyze, synthesize, think critically, solve problems and make decisions; to articulate and apply a public service perspective; to communicate and interact productively with a diverse and changing workforce and citizenry) and their detailed characteristics have been presented. It has been identified that cultural competency of future public administrators has become an essential constituent of public affairs curricula. It has been concluded that the above-mentioned positive aspects of the experience may be used to improve future public administrators' professional training in Ukraine.
\end{abstract}

Key words: public administration, public sector, public affairs, public service, Master of Public Administration (MPA), core competencies, cultural competency, the USA.

\section{INTRODUCTION}

In the context of globalization and integration processes, strengthening of democratic processes, systemic constitutional, administrative, economic, social, educational, administrative and territorial, municipal, regional reforms in Ukraine there is a need for specialists possessing administrative skills to provide administrative services in the public sector, acquainted with the principles, functions and ethics of performance management in state and local governments, able to organize and lead community activities aimed at implementing socially significant projects. Thus, it is of vital importance to enhance the efficiency of public administrators' professional training in native higher education institutions due to the 
application of progressive conceptions so that the reliability and stability of Ukrainian public sector and its respective results may be ensured.

In the way of an autonomous discipline characterized by the alleged general applicability public administration originated in the USA and is still associated with the place of its origin and recognition (Encyclopedia.com, 2016). Public administration in America today is a large and highly complex enterprise made up of thousands of smaller units that encompass the everyday activities of literally millions of citizens and government employees. At the same time it is a field of academic study as well as professional training (Milakovich, Gordon, 2013).

We believe that American experience in training public administrators deserves special attention, as US curricula in Public Administration are well-established, based on verified principles, approaches and methodology and internationally recognized (International Student, 2016).

\section{THE AIM OF THE STUDY}

This paper is aimed at revealing the essence and structure of Masters' of Public Administration professional training in the USA so that positive aspects of the experience may be used to improve future public administrators' professional training in Ukraine.

\section{THEORETICAL FRAMEWORK AND RESEARCH METHODS}

The phenomenon of public administration has been studied by such native scholars as V. Averyanova, V. Bakumenko, V. Bodrov, A. Kolodiy, Yu. Kovbasyuk, I. Kresina, O. Obolenskyi, M. Pasichnyk, Yu. Rymarenko, I. Rozputenko, V. Troshchynskyi, Yu. Sharov, O. Zabuzhko and others.

In the Western philosophical, historical, public and managerial tradition the issues of understanding and conceptualizing public administration have been studied by K. Allen, G. Boston, R. Dahrendorf, D. Feldman, G. Gordon, K. Hood, S. Huntington, D. Ketley, M. Milakovich, D. Osborne, T. Peters, G. Schmidt, L. O'Toole, A. Touraine, A. Verma, D. Waldo, W. Wilson and others.

Despite the relatively profound analysis of the problem mentioned, the structural peculiarities of public administrations' professional training in the USA by native scholars have not been given sufficient attention.

Such methods as synthesis, theoretical analysis, generalization, systematization and prognosis resulted in the conclusion and the perspectives of further scientific researches have been used in the paper.

RESULTS

According to the International Encyclopedia of Social Sciences public administration implies the actions related to effecting the intent of a government. Thus, it is the incessantly active part of government concerned with carrying out the law through the processes of organization and management (Encyclopedia.com, 2016).

Public Administration as the field of study concentrates on public administration as a process. Historically and traditionally Public Administration has been mostly dealing with the issues of applying or effecting law economically and efficiently. Lately Public Administration has been focusing on the procedures through which public administration takes part in establishing and implementing laws in the public interest.

As public administration is becoming more complex and specialized, the professional training of specialists able to perform administrative functions is given increasing attention. However, systematic training for Public Administration is predominantly a contemporary phenomenon. The continuous search for ways to improve public administration and make it 
more efficient is associated with various modern achievements, namely, the rise of the nation-state and science.

It must be noted that $\mathrm{L}$. White and $\mathrm{W}$. Willoughby wrote and published the first two general textbooks on Public Administration in the USA in 1926 and 1927 respectively thus signifying the birth of Public Administration as a discipline. Moreover, in the USA for the past generation the study of public administration has been extremely profound. Consequently, such an intensity of effort has stipulated for a new level of self-consciousness that is reflected in the idea of Public Administration being a sufficiently essential and autonomous science. So, the conception of an autonomous discipline under the title Public Administration is indeed an American idea.

Based on the above, we can draw a conclusion that Public Administration studies the realization of government policies and trains future public administrators for professional activity; is guided by political science and administrative law; aims to improve the justice, equality, security and efficiency of public services.

In general, the Master of Public Administration or MPA degree is dedicated for those willing to work in public sector. MPA programs are designed to develop the abilities, skills and methods specialists use to realize policies, programs and projects as well as to resolve crucial issues within their organization and/or in society.

In the United States of America numerous Master of Public Administration programs (MPA) are similar to Master of Business Administration programs (MBA), thereby MPA and MBA students often take the same courses. Occasionally, the MPA program greatly differs from the MBA one. In these cases, the MPA program emphasizes various ethical and sociological criteria generally secondary to that of profit for business administrators. Some MPA programs encompass economy courses to supply their students with knowledge of microeconomic issues, namely, markets and rationing mechanisms as well as macroeconomic issues, such as national debt.

MPA programs are built on a set of core competencies that are specific knowledge and skills being inherent in public administration. Thus, they represent the essential features of the career field and stipulate for professional readiness through:

- establishing the foundation for successful coopeation, teamwork and communication; fessional success;

- ensuring efficient transfer of knowledge and skills, thereby stipulating for pro-

- providing students and staff with the skills that are necessary for transition to new careers.

Within our paper we have believed it necessary to present the core competences for Masters of Public Administration developed by the Network of Schools of Public Policy, Affairs, and Administration (NASPAA) being an international association of public affairs schools at US and foreign universities as it serves as an accreditor of Master of Public Administration (MPA), Public Policy (MPP) and Public Affairs (MPAff) programs. Its institutional membership covers about 280 university curricula at US higher education institutions. It aims to ensure education quality, train for public sector and stipulate for the efficiency of public service. The association achieves its goals due to:

- designing and implementing relevant standards for curricula in public affairs with the assistance of its Commission on Peer Review and Accreditation as well as Executive Council;

- introducing the educational tasks and needs of public affairs to governments and other organizations; 
- stipulating for the development of curricula and holding discussion on urgent education issues;

- organizing surveys that would supply its participants with data on crucial problems in education;

- collaborating with employers to organize placements and internships as well as to promote further employment;

- launching educational projects together with other organizations;

- cooperating with establishments of public administration abroad by means of conferences and joint projects (National Association of Schools of Public Affairs and Administration (NASPAA), 2016).

In addition, NASPAA provides opportunities for international engagement for NASPAA members, focusing on the quality of education and its enhancement via a series of interrelated organizations, in particular, the Network of Institutes and Schools of Public Administration in Central and Eastern Europe (NISPAcee), the Inter-American Network of Public Administration Education (INPAE) and the Georgian Institute of Public Affairs (GIPA). It also directs the Small Communities Outreach Project for Environmental Issues that involves local authorities together with public affairs schools supported by the Environmental Protection Agency.

Thus, NASPAA requires each accredited MPA program to deliver five core competencies to its students. However, the programs are allowed to define each competency and determine the courses in which they will be delivered. So, the core competences are to:

1) lead and manage in public governance;

2) participate in and contribute to the public policy progress;

3) analyze, synthesize, think critically, solve problems and make decisions;

4) articulate and apply a public service perspective;

5) communicate and interact productively with a diverse and changing workforce and citizenry (Network of Schools of Public Policy, Affairs, and Administration (NASPAA), 2014).

The above-mentioned competencies encompass vital aspects of future public administrators' professional activity, so it is important to analyze each of them in detail.

Thereby, in order to lead and manage in public governance students are to comprehend the main roles of public administration in social environments; the context of public and nonprofit management as well as how it contrasts private sector management; how organizational theory and behaviour can be applied to organizational improvement. In addition, students should be able to set mission-driven goals as well as use economic concepts, relevant data, performance indicators and various approaches to manage and lead in service of mission; to apply theories of leadership to motivate people, build terms and manage changes; to effectively allocate and manage financial and programmatic resources. Finally, they are to be self-aware and manage and lead with emotional intelligence.

To participate in and contribute to the public policy process future public administrators must understand the process and context of policy making at all levels of democratic government. Consequently, they should know how to apply tools for engaging citizens in the policy processes and techniques for generating and selecting among policy alternatives. Furthermore, students are supposed to identify common barriers so that they may be effectively implemented and overcome. It is important for them to know how policy and administrative process are connected. 
To analyze, synthesize, think critically, solve problems and make decisions future specialists should be able to choose and use relevant research methods and analytical tools for collecting and analyzing data; to find and synthesize existing data to inform decisions; to critically assess, review and understand research activities; to apply different perspectives and assumptions to generate policy and management decision alternatives. Additionally, students are to understand the factors influencing the decision-making process to be able to select and use appropriate criteria and processes for making decisions. Also, they are supposed to apply different ethical maps so that ethical conflicts may be resolved.

To articulate and apply a public service perspective students are to understand and apply professional codes of ethics to situations and decisions; to adhere to policies and practices advancing government and nonprofit transparency and accountability. They should be acquainted with public service values and public integrity. Eventually, future public administrators are to possess tools for identifying and dealing with conflicts between ethical values.

To communicate and interact productively with a diverse and changing workforce and citizenry students should understand and appreciate the value of diverse backgrounds and viewpoints in a democracy. Thus, they are to be able to partner effectively and work in teams to achieve goals; to communicate effectively in writing and in a spoken format to a variety of audiences. As a result, they must understand the value of and be able to effectively incorporate citizen participation as well as comprehend the diverse workforce and know how to engage and manage it. Finally, students are to recognize and manage the ethics of competing values.

It should be noted that cultural competency of future public administrators has become an essential constituent of public affairs curricula as it provides for the increased efficiency of the public service (Carrizales, 2010).

In the guidelines designed for public affairs schools that are seeking accreditation, NASPAA suggests the concept of diversity in curricula. It states that public affairs graduates should operate in increasingly diverse settings, thereby educational material must familiarize students with issues related to gender and race and stipulate for their ability to work efficiently with representatives of various cultural backgrounds" (National Association of Schools of Public Affairs and Administration (NASPAA), 2009).

Cultural competency has many interpretations being applicable to different organizations providing services. However, each definition is stressed by a general focus on ensuring better serve for its clients.

For instance, A. Fernandopulle refers to cultural competency as the "organizations and persons' ability to effectively operate in both inter- and multicultural interactions". Furthermore, the competency describes a scope of developmental stages (Fernandopulle, 2007).

T. Lonner considers cultural competency to be a continuum "with no endpoints; that is, there is neither an exact bottom for total cultural incompetence nor an exact top measure" (Lonner, 2007).

The National Center for Cultural Competence (NCCC) defines cultural competency as "the knowledge, skills, and values needed to effectively cooperate with various ethnic groups and to adjust institutional policies and professional practices so that the unique needs of client populations may be fulfiled" (Satterwhite, Teng, 2007).

Therefore, it is critical for public affairs programs to introduce cultural competency into their curriculum. It has been found out that cultural competency consists of such components as knowledge-based, attitude-based, skills-based and community-based (Carrizales, 2010). 
Content examples for knowledge-based component include definitions and terms, local and national demographics, discussions of societal disparities and social equity and an understanding of the legal and policy implications of cultural competency. Attitude-based component covers self-reflection, societal biases, organizational culture/change. A skillsbased curriculum is built on existing public affairs skills such as communication, leadership and program planning and evaluation, yet it incorporates both the knowledge- and attitudebased curriculum to translate into cultural competent skills.

So, collectively, knowledge, attitude and skills-based components ensure a culturally competent public sector. However, all three components can be significantly enhanced by incorporating the community (Carrizales, 2010).

\section{CONCLUSIONS}

So, we can conclude that Public Administration studies the realization of government policies and trains future public administrators for professional activity; is guided by political science and administrative law; aims to improve the justice, equality, security and efficiency of public services.

Consequently, the Master of Public Administration or MPA degree is dedicated for those willing to work in public sector. MPA programs are designed to develop the abilities, skills and methods specialists use to realize policies, programs and projects as well as to resolve crucial issues within their organization and/or in society.

In the United States of America there are Master of Public Administration programs (MPA) and Master of Business Administration programs (MBA) being quite similar, however, having certain differences. It has been indicated that the MPA program focuses on different ethical and sociological criteria secondary for business administrators. Simultaneously MPA programs encompass economy courses to supply students with knowledge of microeconomic and macroeconomic issues.

It has been found out that MPA programs are built on a set of core competencies defined by the Network of Schools of Public Policy, Affairs, and Administration (NASPAA). These competences are to

1) lead and manage in public governance;

2) participate in and contribute to the public policy progress;

3) analyze, synthesize, think critically, solve problems and make decisions;

4) articulate and apply a public service perspective;

5) communicate and interact productively with a diverse and changing workforce and citizenry.

It has been stated that cultural competency of future public administrators has become an essential constituent of public affairs curricula as it increases the efficiency of the public sector. Its main components are knowledge-based, attitude-based, skills-based and community-based.

Therefore, the accumulated experience of American educators in realizing professional training of public administrators allows to state that the profession is the most in-demand there due to well-established principles and approaches applied to the training as well as the activities of relevant organizations aimed to expand the scope of the field and provide future specialists with necessary knowledge and skills.

Thus, the above-mentioned positive aspects of the experience may be used to improve future public administrators' professional training in Ukraine.

Rather perspective for further researches we consider theoretical analysis of the content of public administrators' professional training in the countries of the European Union. 


\section{REFERENCES}

1. Encyclopedia.com. (2016). Public Administration. Retrieved 8.10.2016 from : http://www.encyclopedia.com/social-sciences-and-law/law/law-divisions-and-codes/publicadministration.

2. Carrizales, T. (2010). Exploring Cultural Competency within the Public Affairs Curriculum. Journal of Public Affairs Education, No 16 (4), pp. 593-606.

3. Fernandopulle, A. (2007). A Capacity Building Approach to Cultural Competency: Improving Cultural Competency Improves Organizational Effectiveness. In : Organizational Development and Capacity in Cultural Competence (Los Angeles : The California Endowment and San Francisco: CompassPoint Nonprofit Services). Retrieved 8.10.2016 from : http://www.compasspoint.org/assets/496_satterwhitefull.pdf.

4. International Student. (2016). Study Public Administration in the US. Retrieved 8.10.2016 from : http://www.internationalstudent.com/study-public-administration/.

5. International Student. (2016). Why Study Public Administration. Retrieved 8.10.2016 from : http://www.internationalstudent.com/study-public-administration/why-studypublic-administration/.

6. Lonner, T. D. (2007). Encouraging More Culturally and Linguistically Competent Practices in Mainstream Health Care Organizations: a Survival Guide for Change Agents. In : Organizational Development and Capacity in Cultural Competence (Los Angeles : The California Endowment and San Francisco: CompassPoint Nonprofit Services). Retrieved 8.10.2016 from : https://www.compasspoint.org/sites/default/files/documents/Lonner_full.pdf.

7. Milakovich, M., Gordon, G. (2013). Public Administration in America. Boston : Cengage Learning, $672 \mathrm{p}$.

8. National Association of Schools of Public Affairs and Administration (NASPAA). (2009). Diversity Guideline. Retrieved 8.10.2016 from : http://www.naspaa.org/accreditation/ seeking/reference/guidelines. asp\#diversity.

9. Network of Schools of Public Policy, Affairs, and Administration (NASPAA). (2016). About NASPAA. Retrieved 8.10.2016 from : http://www.naspaa.org/about naspaa/naspaa.asp.

10. Network of Schools of Public Policy, Affairs, and Administration (NASPAA). (2014). Accreditation Standards for Master's Degree Programs. Retrieved 8.10.2016 from : https://naspaaaccreditation.files.wordpress.com/2015/02/naspaa-accreditationstandards.pdf.

11. Satterwhite, F. J. O., Teng, S. (2007). Culturally Based Capacity Building: An Approach to Working in Communities of Color for Social Change. In : Organizational Development and Capacity in Cultural Competence (Los Angeles : The California Endowment and San Francisco: CompassPoint Nonprofit Services). Retrieved 8.10.2016 from : http://www.compasspoint.org/assets/496 sat- terwhitefull.pdf. 